IJIET, e-ISSN 2548-8430, p-ISSN 2548-8422, Vol. 1, No. 2, July 2017

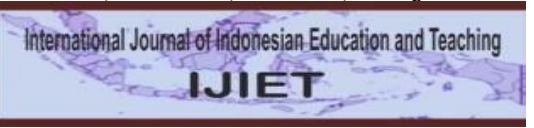

International Journal of Indonesian Education and Teaching http://e-journal.usd.ac.id/index.php/IJIET

Sanata Dharma University, Yogyakarta, Indonesia

\title{
PPR IMPLEMENTATION IN MICRO TEACHING COURSE TO IMPROVE STUDENTS' CONFIDENCE AND COMPASSION
}

\author{
Haniek Sri Pratini \\ Mathematics Education Study Program \\ Faculty of Teachers Training and Education, Sanata Dharma University \\ haniek_sp@yahoo.com \\ https://doi.org/10.24071/ijiet.2017.010201 \\ received 10 November 2016; revised 21 March 2017; accepted 1 July 2017
}

\begin{abstract}
This research aims to describe the implementation of Paradigm of Reflective Pedagogy (PPR) in Micro Teaching course by providing experiences to students to facilitate learning with more compassion and careful time management for effective learning. By implementing PPR in Micro Teaching course, students are expected to have Competence (the ability to perform basic teaching skills), Conscience (confidence in performing the basic teaching skills), and Compassion (concern to the students' responses in the learning process). The implementation results showed that out of 22 students, as many as 16 students $(72.73 \%)$ got A's and 6 students $(27.27 \%)$ got B's. The average score on Competence aspect was 82, 89 on Conscience aspect and 84 on Compassion aspect.
\end{abstract}

Keywords: paradigm of reflective pedagogy, basic teaching skills, confidence, compassion

\section{Introduction}

Mathematics student teachers are required to master four teaching competencies, namely pedagogical competence, professional competence, personal competence and social competence. The four competencies are sharpened during their study at the undergraduate level. Achievement of competence begins with the mastery of various subjects, either related to the science of mathematics and mathematics learning. Comprehensive student competencies are examined when they follow PPL (Field Experience Program) activity. The last experience before PPL related to the mastery of the four competencies is Micro Teaching course. Through micro teaching, students are trained to master the competencies of opening and closing the lesson, explaining and providing stimulus, asking questions and providing reinforcement, as well as integrating all competencies in learning. Mastery of these competencies also include mastery of the materials, the use of learning strategies, the selection of relevant media, learning that engages students, appearance and time management, classroom management, and the use of language and writing system. It is expected that the mastery of those competencies can equip students to be ready for the PPL 
activity. In this case, ready means minimizing complaints from PPL teachers at school stating that the students did not master the materials, were unable to control classes, and gave less attention to the students in general. Therefore, PPR implementation provides a learning experience that gives more emphasis on the mastery of learning materials, classroom management with more compassion when engaging students in learning, and careful time management for effective learning.

\section{Paradigm of Reflective Pedagogy (PPR)}

Lectures given by lecturers should continuously seek ways to help students to develop into a whole human being. This is in line with Rohandi's opinion (2015: 6) who said that the essence of education is a conscious effort to do any form of quality and sincere action in educating that is based on compassion and generosity. Paradigm of Reflective Pedagogy (PPR) is seen to help students develop into a whole human being. Suparno (2015: 18) said that PPR is a way for lecturers to assist students so that students develop themselves into whole human beings. Students' transformation into whole human beings means that students develop into competent people in their field, have a right conscience and have compassion which grows from their concern of others. It was stated by Kolvenbach (in Subagya, 2012: 23). The learning process is designed for a student-centered learning, so that students are able to live conscientiously to gain knowledge and live in true conscience and concerns for others with full responsibility.

According to Suparno (2015: 28), there are five stages in implementing PPR in learning, namely: context, experience, reflection, action and evaluation. Those stages are presented in the following diagram.

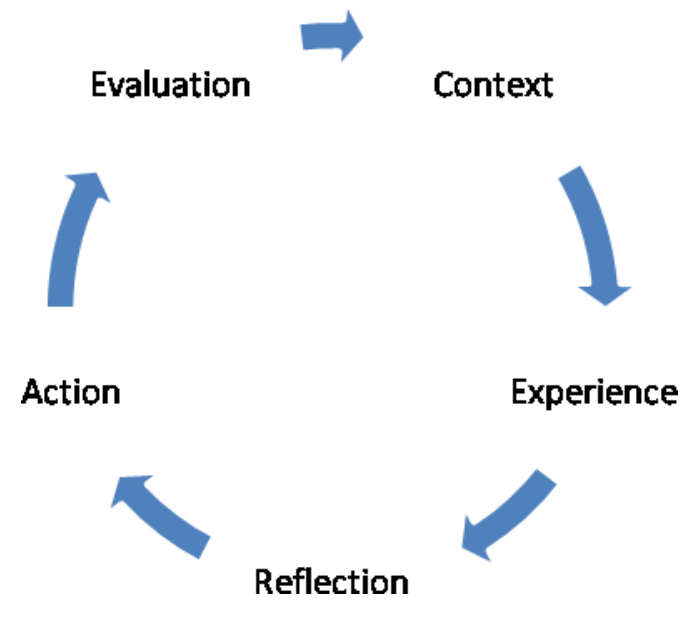

\section{Context}

Context is interpreted as the learning context that includes students, the environment, and universities. Students' context include all situations related to students, such as family background, social environment, religion, ideals or life goals, readiness to learn, the pre-conceived concept, and students' learning styles. Lecturers utilize an understanding of the students' context to choose relevant 
teaching methods to facilitate the learning goals achievement for students. Environmental context includes all situations related either directly or indirectly with the students' activities such as: socio-economics and politics, culture, media and elements that can serve as learning sources. Wherever possible, lecturers should make use of the environment as a learning source so that students can feel the contextual learning in order to ease the students in achieving their learning goals. University environment context that houses the students include; academic atmosphere, friendship / brotherhood, moral values, work ethics, institutional organizations as well as student organizations. Lecturers monitor the students to live up to these values to achieve success in learning.

\section{Experience}

Lecturers have a role in designing experiences so that students experience for themselves how to use the materials, persevere, struggle and reap the meaning of learning so that the experience become theirs. Experience in learning is facilitated by the learning model used. Lecturers choose learning models that can explore the students' active participation. Students are expected to be physically and mentally active, so that students experience the process of designing materials and draw meaning for their lives from the process.

\section{Reflection}

Reflection is a process of drawing meaning from experience. This is done by tapping into past lived experiences deeply in order to draw meaning for personal life, living together, and social life. The experience in designing the materials using a variety of methods facilitated by the lecturers is reviewed in order to seek meaning for everyday life. Reflection is not an easy task for students. Therefore, it should be guided by lecturers through the reflective questions which guide students to dig deeper into their experience and interpret it. Action

Action is either mental or psychomotor action that is performed after the students discover the meaning of their learning experience. Action is a follow-up activity of reflection. Action is manifested in better attitudes and real action that can be perceived by other people or the environment.

\section{Evaluation}

Evaluation is the giving an assessment to the experience, reflection, and action on whether they have been running well so that students become more competent in their field of knowledge, have a right conscience, and a sensitivity to the needs of others.

PPR implementation on this course is believed to help students optimally in terms of competence aspect, namely: performing basic teaching skills (opening and closing the lesson, explaining and providing stimulus, as well as asking questions and providing reinforcement); preparing lesson plans (RPP) in accordance with applicable school curriculum; and implementing the lesson plans that had been developed. In terms of conscience, namely: developing confidence in performing the basic teaching skills (confident because they believe in the accuracy of the method chosen for teaching the topics), increasing enthusiasm in performing the basic teaching skills of opening and closing the lesson (enthusiastic because they believe in the importance of opening and closing 
correctly), careful attitude in performing the skills of explaining and providing stimulus (carefully because they believe in the importance of details from the aspects of explaining and providing a stimulus for the materials mastery by the students), and a creative attitude in performing skills of asking questions and providing reinforcement (creative because they believe in the importance of formulating questions and providing various stimulus for the creation of learning that is not boring for the students). In terms of compassion, namely: building a responsiveness to the students' responses in learning and caring attitude towards students' responses in the learning undertaken as the embodiment of compassion for the students who follow the lessons. PPR implementation in Micro Teaching is expected to help achieve the vision and mission of the study program, in which the vision is to forge humanist and professional mathematics teacher candidates. Meanwhile, one of its missions is to prepare students to become mathematics teacher candidates who have pedagogic competence, professional competence, personal competence and social competence, who have empathy towards the problems faced by the students and to respect plurality.

\section{Method}

This study was a descriptive study aiming to describe the phenomenon factually and accurately (Ibnu Hajar, 1996: 274). The phenomenon referred to in this research was the learning activities which implemented PPR in the Micro Teaching course. The description of the phenomenon was presented quantitatively. The research subjects were 22 sixth semester students of Mathematics Education Study Program in Sanata Dharma University who were enrolled in Micro Teaching course. The object of this research was the implementation of PPR in Micro Teaching course. The data obtained in this research were 1) quantitative data in the form of observation score on the mastery of the materials (competence), confidence (conscience), and concern for students (compassion) and 2) qualitative data in the form of reflection and students' action at the end of a cycle. Data were obtained by 1) observing the teaching practice conducted for each teaching skill in each cycle and 2) filling out the questionnaire for reflection and students' action after performing teaching practices. Instruments used for data collection were in the form of observation guidelines and reflection questionnaires developed by Faculty of Teachers Training and Education's team of Sanata Dharma University. The questionnaire developed by the team was a reflection questionnaire, but one of the question items can be used as a question for action.

\section{Findings and Discussion \\ First Cycle}

Context of the students enrolled in Micro Teaching course is the sixth semester students who have passed the pre-requisite courses of this course, namely: Junior High School Mathematics Learning, Senior High School Mathematics Learning, Mathematics Learning Planning and Mathematics Learning Evaluation in addition to courses related to mathematics materials in middle school. Through the Junior High School Mathematics Learning and Senior 
High School Mathematics Learning courses, students have the opportunity to observe the mathematics learning process in junior and senior high schools, so they have understood what mathematics learning situation in junior or senior high schools is like. Furthermore, students also have already experienced teaching their friends in the teaching simulation as well as a group of junior and senior high school students, so that they already have a sense of teaching. Through Mathematics Learning Planning course, students have the opportunity to design learning with various methods and learning media, so they can conduct their teaching preparation in Micro Teaching more smoothly. Through Mathematics Learning Evaluation course, students have the opportunity to design various types / forms of assessment and testing them to junior or senior high school students. Through the courses related to mathematics materials in middle schools, the students receive materials reinforcement, so it is expected that there will be no problems related to the materials during Micro Teaching.

Experience that is given in the first cycle begins by giving an example of basic teaching skills practice models of opening and closing the learning. Students are given the opportunity to observe a video showing teacher candidates doing teaching practice, and then students criticize the teaching practice conducted and propose improvement measures for the teaching practice based on the theoretical knowledge that they have obtained previously. In the next stage, the students get the opportunity to practice opening and closing the lessons. The topics / basic competence (KD) which become the subject of learning are mathematics topics / $\mathrm{KD}$ in the junior / senior high school which are chosen by the students with the requirement that each student chooses a different topic / KD. Practices are carried out in 15 minutes. Practices are set in several meetings, in which 5 students get the opportunity to perform the practice each meeting. A student's practice is set by a supervisor who is in charge of checking the students who serve as observers (1 verbal observer and 1 written observer), delivering topics that will be taught by the practitioner to other students who serve as students, and setting the process of delivering the verbal evaluation from the verbal observer and from the supervisor to the practitioner. It is repeated again using the same procedure for the second basic teaching skills (explaining and providing stimulus) and the third teaching (asking questions and providing reinforcement).

Reflection on the practice that has been conducted is done individually by the practicing students immediately after completing the learning practice. Students feel happy because they can carry out the basic teaching skills practice according to what they expect, and they also feel relieved to have completed the first cycle by practicing the three basic teaching skills. Some students are still not satisfied with their teaching practice performance.

Action is formulated in writing in every practitioner's reflection sheet. Action is made based on the reflection that has been done by the students. Actions are in the form of intention to minimize errors / flaws when they practice the integrated teaching skills. Integrated teaching skills will be implemented in cycle 2.

Evaluation of the activities in the first cycle is conducted during the integrated teaching skills practice, so it is conducted during the process. Students 
evaluate their teaching practices. The results of the process evaluation are: some students still find it difficult to find / create examples in everyday life related to the topics / KD practiced in order to motivate students; some students still find it difficult to find the idea of the media / teaching aids that should be used to explain specific topics / KD; difficulties in managing the time; they often use informal language; they make mistakes in explaining the subject matter; they still have not done all aspects of closing the lesson completely due to limited time. The evaluation results of the competence, conscience and compassion aspects can be seen in Table 1 below.

Table 1. Assessment on competence, conscience and compassion aspects in limited basic teaching skills

\begin{tabular}{l|l}
\hline \multicolumn{2}{c}{ Cycle 1 } \\
\hline Aspect & Limited basic teaching skills \\
\hline Competence & 91 \\
\hline Conscience & 97 \\
\hline Compassion & 86 \\
\hline
\end{tabular}

The scores shown in Table 1 are the average score from the three limited basic teaching skills performed. The students choose topics or basic competence that can be optimized to explore the skills of opening and closing the lesson, explaining and providing stimulus, as well as asking questions and giving reinforcement.

\section{Second Cycle}

Context of the students of the course are still the same students from the previous cycle, but they have increased their competence in basic teaching skills of opening and closing the lesson, explaining and giving stimulus, as well as asking questions and giving reinforcement separately.

Experience given in the second cycle is the experience that strengthens the experience in the first cycle, which is done by integrating basic teaching skills. Students are given the opportunity to observe a video showing teacher candidates doing integrated teaching skills practice, and then students criticize the practice of learning conducted and propose ways to improve the teaching practice based on the guidelines of the learning observation. Students get the opportunity to practice integrated teaching skills. Topics / basic competence (KD) that become the subject of learning are mathematics topics / KD in junior high school level which are chosen by the students provided that each student chooses a different topic / KD. Practices are carried out in 30 minutes. Practices are set in several meetings, in which three students have the opportunity to practice each meeting. The role divisions in the practice activities are the same as those in the first cycle, namely: supervisor, verbal observer, written observer, and students.

Reflection is done by every practicing student immediately after completing the integrated teaching practice. Students feel happy and confident when they successfully practice the integrated teaching skills. Furthermore, they feel excited 
/ enthusiastic in finding ways / methods to deliver the materials that can ease the students in understanding the materials.

Action is done based on the reflection that has been done individually by the students and based on the feedback from the lecturer and the observers. Actions taken are formulating intention to minimize errors / failings when they practice the last integrated teaching skills practice. The last integrated teaching skills practice will be conducted in cycle 3 .

Evaluation of the activities in the second cycle is conducted during the integrated teaching skills practice. The results of the process evaluation are some students still find it difficult to find / give real-life examples related to the topic / $\mathrm{KD}$ that will be practiced in order to motivate students; some students still find it difficult to find the idea of the media / teaching aids that should be used to explain certain topics / KD; some students still have difficulties in managing the time; some students often use informal language; some students still make mistakes in explaining the subject matter. Students make fewer mistakes than in the first cycle. The evaluation results of the competence, conscience and compassion aspects can be seen in Table 2 below.

Table 2. Assessment on competence, conscience and compassion aspects in integrated teaching skills for mathematics topic in Junior High School

\begin{tabular}{l|l}
\hline \multicolumn{2}{c}{ Cycle 2 } \\
\hline Aspect & Integrated teaching skills \\
\hline Competence & 91 \\
\hline Conscience & 88 \\
\hline Compassion & 90 \\
\hline
\end{tabular}

The scores shown in the above table are the average score from the competence, conscience and compassion indicators. The students choose Junior High School mathematics topics or basic competence that can be optimized to explore integrated basic teaching skills.

\section{Third Cycle}

Context The context of the students are still the same students from the students in cycle I and II, but they have acquired the competence of: opening and closing the lesson, explaining and giving stimulus, as well as asking questions and giving reinforcement integrated. The material trained in the learning is mathematics in Senior High School level.

Experience given in the third cycle is the integrated teaching skills practice using mathematics materials in Senior High School level. This is trained so that students can master the teaching skills integrated (because it has been done twice) and increase their materials mastery in the Senior High School level. Topics / basic competence $(\mathrm{KD})$ that become the subject of learning are mathematics topics / KD in senior high school level which are chosen by the students with a requirement that each student chooses a different topic / KD. Practices are carried out in 45 minutes which is in accordance with the implementation of 1 (one) contact hour in senior high schools. Practices are set in several meetings, in which 
two students get the opportunity to perform the practice each meeting. The role divisions in the practice activities are the same as those in the second cycle, namely: supervisor, verbal observer, written observer, and students.

Reflection is done by every practicing student immediately after completing the integrated teaching practice. Students feel happy and more confident in teaching. Furthermore, they feel more enthusiastic in following the learning process conducted by their fellow practicing students because they can be involved in the implementation of various methods to deliver the materials. Students find meaning from this integrated teaching skills practice to truly prepare themselves to be mathematics teachers. Students also come to awareness that mathematics is a subject that is considered difficult by the students so they have to try to make mathematics easy for the students. The implication is that students have to be creative in finding ways / methods and media that can help them do that.

Action is made based on the reflection that has been done individually by the students and based on the feedback from the lecturer and the observers. The actions included formulating intention to minimize errors / flaws when they do the teaching practices at schools, which is when they do the Field Experience Program (PPL) at schools in the next semester.

Evaluation of the activities in the third cycle is conducted when the students perform their second integrated teaching skills practice. The evaluation is conducted by the lecturer and the students who act as observers. The evaluation results on the aspects of competence, conscience and compassion can be seen in Table 3 below.

Table 3. Assessment on competence, conscience and compassion aspects in integrated teaching skills for mathematics topic in Senior High School

\begin{tabular}{l|l}
\hline \multicolumn{2}{c}{ Cycle 3 } \\
\hline Aspect & Integrated teaching skills \\
\hline Competence & 94 \\
\hline Conscience & 89 \\
\hline Compassion & 94 \\
\hline
\end{tabular}

The scores shown in the above table are the average score from the competence, conscience and compassion indicators. The students choose Senior High School mathematics topics or basic competence that can be optimized to explore integrated basic teaching skills. Students' competence achievement from cycle 1 until cycle 3 can be seen in diagram 1 below. 


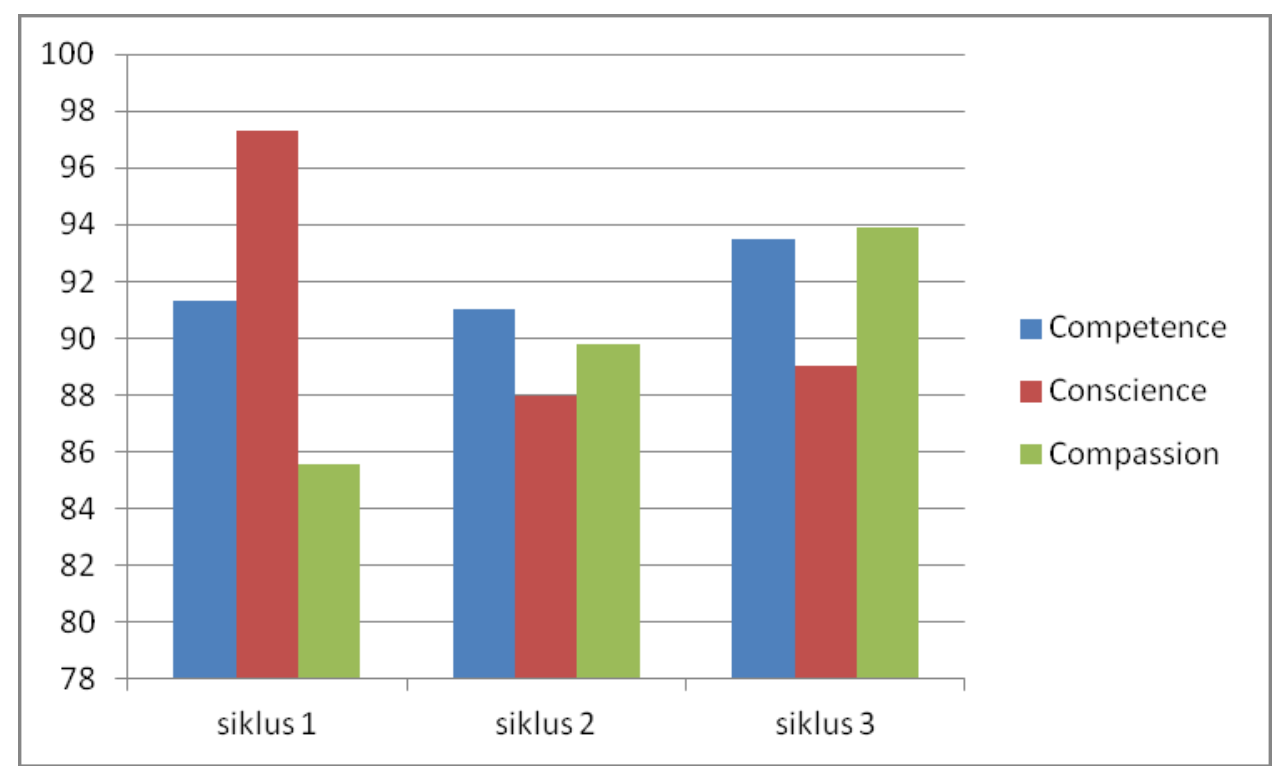

\section{Diagram 1. Competence achievement from Cycle 1, 2 and 3}

The competence achievement at the end of cycle 3 is the accumulation of competence achievement in cycle 1 and 2 . This happens because in cycle 1 , the trained teaching skills are still limited. In cycle 2, they begin to train integrated teaching skills using Junior High School mathematics topics and continues to cycle 3 which also trains integrated teaching skills using Senior High School mathematic topics. If the achievement of competence in cycle 1 appears to be higher than cycles 2 and 3, it is natural since the training is still limited. Limited training is certainly easier to do than integrated skills training.

The ultimate achievement of the course showed that out of 22 students, as many as 16 people (72.73\%) got an A and 6 people (27.27\%) obtained a B. The average score was 82 for the competence aspect, 89 for the conscience aspect, and 84 for the compassion aspect.

\section{Conclusions}

Learning outcomes can be seen from the achievement of competence aspect with an average score of 82 , conscience aspect with an average score of 89 , and compassion aspect with an average score of 84 . Competence aspect includes: 1) the ability to practice the skills of opening and closing the lesson; 2) the ability to practice the skills of explaining and providing stimulus; 3 ) the ability to practice the skills of asking questions and providing reinforcement; 4) the ability to draft lesson plans (RPP) in accordance with applicable school curriculum; and 5) the ability to implement the lesson plans that had been prepared. Conscience aspect includes: 1) confidence in practicing the basic teaching skills; 2) enthusiasm in practicing opening and closing the lesson skills; 3 ) a careful attitude in practicing skills to explain and provide stimulus; 4) creativity in practicing skills in asking questions and providing reinforcement; and 5) the attitude that shows high spirit in implementing mathematics learning. Compassion aspect includes: 1) 
responsiveness to the students' responses in the learning and 2) a caring attitude towards the students' responses in the learning performed.

It is recommended to carry out learning with PPR approach continuously so that students are more aware of the true nature of education which is to develop the students (and lecturers) into a whole human being in terms of competence, conscience and compassion. The implication of the implementation of PPR is mathematics teacher candidates who master the materials well, have a good conscience, and have a high concern for the students to participate in learning.

\section{References}

Hadjar, I. (1996). Dasar-dasar metodologi penelitian kwantitatif dalam pendidikan. Jakarta: Raja Grafindo Persada.

Rohandi, dkk (2013). Pedoman pengajaran mikro. Yogyakarta: Fakultas Keguruan dan Ilmu Pendidikan Universitas Sanata Dharma.

Rohandi. (2015). Pedagogi transformatif: Membuka hati dan pikiran untuk merawat kehidupan. Yogyakarta: Universitas Sanata Dharma.

Subagya, dkk. (2012). Paradigma pedagogi reflektif: Mendampingi peserta didik menjadi cerdas dan berkarakter. Yogyakarta: Kanisius.

Suparno, P. (2015). Paradigma pedagogi refleksi (PPR). Yogyakarta: Universitas Sanata Dharma.

Tim Penyusun P3MP. (2012). Pedoman model pembelajaran berbasis Pedagogi Ignasian. Yogyakarta: Lembaga Penjaminan Mutu Universitas Sanata Dharma. 